\title{
Homozygous familial hypercholesterolemia due to APOB genetic variant with unusual clinical course
}

\author{
Krzysztof Chlebus' ${ }^{1}$ Marta Żarczyńska-Buchowiecka², Marcin Pajkowski², Magdalena Chmara ${ }^{3}$, Tycho R Tromp ${ }^{4}$, \\ Marcin Gruchała'
}

$11^{\text {st }}$ Department of Cardiology, Medical University of Gdansk, Gdańsk, Poland

2Department of Cardiac Diagnostics, Medical University of Gdansk, Gdańsk, Poland

${ }^{3}$ Department of Biology and Medical Genetics, Medical University of Gdansk, Gdańsk, Poland

${ }^{4}$ Department of Vascular Medicine, Amsterdam UMC, location AMC, Amsterdam, Netherlands

\section{Correspondence to:}

Krzysztof Chlebus, MD, PhD,

$1^{\text {st }}$ Department of

Cardiology, Medical

University of Gdansk

ul. Dębinki 7,

80-211 Gdańsk, Poland,

phone: + 48583492500

e-mail:

chlebus@gumed.edu.pl

Copyright by the Author(s), 2021

Kardiol Pol. 2021;

79 (9): 1030-1031;

DOl: 10.33963/KP.a2021.0034

Received:

May 14, 2021

Revision accepted:

June 11, 2021

Published online:

June 11, 2021
A 29-year-old patient was admitted to our center with suspected familial hypercholesterolemia (FH). The patient had no comorbidities, nor was she taking any medications. Her lipid profile was: total cholesterol $248 \mathrm{mg} / \mathrm{dl}$, low-density lipoprotein cholesterol (LDL-C) $191 \mathrm{mg} / \mathrm{dl}$, high-density lipoprotein cholesterol (HDL-C) $44 \mathrm{mg} / \mathrm{dl}$, and triglycerides $64 \mathrm{mg} / \mathrm{dl}$. Physical examination showed no relevant abnormalities. Mean carotid intima-media thickness was $0.37 \mathrm{~mm}$ and $0.49 \mathrm{~mm}$ in the left and right internal carotid arteries and coronary calcium score was 2. The patient scored 4 on the Dutch Lipid Clinic Network scale which is a diagnostic tool for FH. Next-generation sequencing revealed a homozygous variant in the apolipoprotein $B(A P O B)$ gene (c.10580G>A p.[Arg3527Gln]). Moreover the heterozygous APOE rare variant, denoted as C.460C > T p. (Arg154 Cys), was pres- ent in the patient. In the course of the cascade screening, we acquired data concerning the proband's family (Figure 1). Detailed analysis of family history revealed that the parents of the proband were $2^{\text {nd }}$ line cousins. Dietary consultation and rosuvastatin $20 \mathrm{mg}$ daily with ezetimibe $10 \mathrm{mg}$ daily were prescribed with $\mathrm{LDL}-\mathrm{C}$ reduction to $62 \mathrm{mg} / \mathrm{dl}$ by $67 \%$.

According to WOBASZ II (Wieloośrodkowe Badanie Stanu Zdrowia Ludności, Multi-center National Population Health Examination Survey), lipid disorders and unsatisfactory treatment efficacy remain a major problem in the Polish population [1]. Inherited lipid abnormalities referred to as $\mathrm{FH}$ is genetically heterogeneous and the most common are variants within LDL receptor $(L D L R), A P O B$, and proprotein convertase subtilisin/kexin type 9 (PCSK9) genes. Hypercholesterolemia

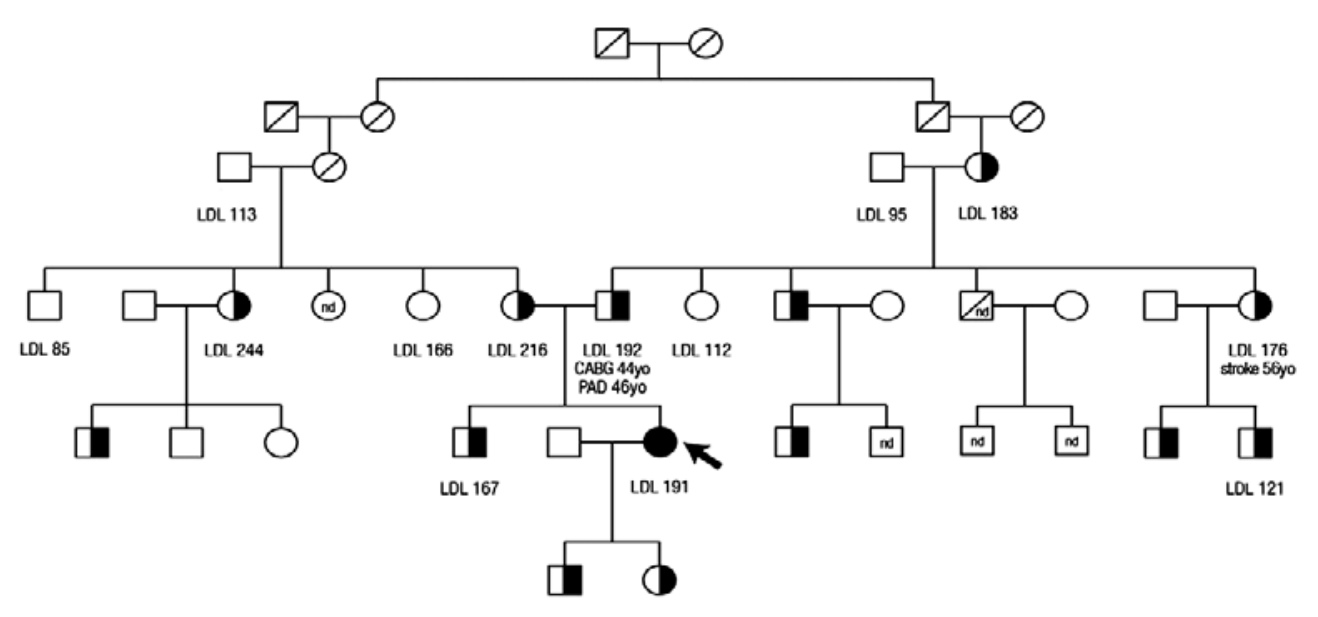

Figure 1. Pedigree of family. Numbers indicate low-density lipoprotein cholesterol (LDL-C) in mg/dl

Arrow - proband. Abbreviations: CABG, coronary artery bypass grafting; PAD, peripheral artery disease; nd, no data; yo, years old 
due to $A P O B$ defect (FDB, familial defective $A P O B)$ is rare with a prevalence of 1:1000 and 1:4 000000 for heterozygous and homozygous, respectively [2]. Homozygotes were observed in populations with the founder effect as well as in descendants of consanguineous parents, which is probably the case [3]. The most common pathogenic variant detected in the $A P O B$ gene results in reduced LDLR binding capacity, up to $25 \%$, which leads to an accumulation of LDL-C [4]. Only a few cases of patients with homozygous FDB have been described in the literature and this is the first $A P O B$ homozygote case in the Polish population [2]. Homozygous $\mathrm{FH}(\mathrm{HoFH})$ is characterized by severe clinical presentation and classically is defined by LDL-C levels of $\geq 500 \mathrm{mg} / \mathrm{dl}$ in untreated patients, and $\geq 300 \mathrm{mg} / \mathrm{dl}$ in treated subjects with cutaneous or tendinous xanthoma occurring at less than 10 years of age [2]. Patients with pathogenic variants in $A P O B$ may have a milder clinical presentation, and the present case constitutes a documented example of this. As described in the literature, the average LDL-C concentrations found in cases of homozygous FDB were $265-331 \mathrm{mg} / \mathrm{dl}$, and were lower in younger individuals, which may, at least partially, explain the proband's surprisingly low level of $\operatorname{LDL}-\mathrm{C}[2,5]$. Causes of the relatively low LDL-C levels are sought in the apolipoprotein-E-dependent increased clearance of LDL-C precursor particles and the mechanism of up-regulation of the LDLR $[3,4]$. Patients with HoFH do not attain satisfactory results of standard treatment and therapy must often be extended to include PCSK9 inhibitors or LDL-apheresis. The fact that the therapeutic objective is not achieved in patients with HoFH is particularly significant, as they are in the group of very high cardiovascular risk.

The described case of HoFH presented an unusual clinical course, even for FDB individuals, and underlines the necessity of a critical and individual assessment of all subjects with suspected $\mathrm{FH}$.

\section{Article information}

Acknowledgments: This study was supported by grant from National Science Centre Poland, project no. UMO-2015/19/B/NZ5/03510.

Conflict of interest: None declared.

Open access: This article is available in open access under Creative Common Attribution-Non-Commercial-No Derivatives 4.0 International (CC BY-NC-ND 4.0) license, allowing to download articles and share them with others as long as they credit the authors and the publisher, but without permission to change them in any way or use them commercially. For commercial use, please contact the journal office at kardiologiapolska@ptkardio.pl.

How to cite: Chlebus K, Żarczyńska-Buchowiecka M, Pajkowski M, et al. Homozygous familial hypercholesterolemia due to $A P O B$ genetic variant with unusual clinical course. Kardiol Pol. 2021; 79(9): 1030-1031, doi: 10.33963/KP.a2021.0034.

\section{REFERENCES}

1. Niklas A, Marcinkowska J, Kozela M, et al. Blood pressure and cholesterol control in patients with hypertension and hypercholesterolemia: the results from the Polish multicenter national health survey WOBASZ II. Pol Arch Intern Med. 2019; 129(12): 864-873, doi: 10.20452/pamw.15013, indexed in Pubmed: 31596271.

2. Foody JM, Vishwanath R. Familial hypercholesterolemia/autosomal dominant hypercholesterolemia: Molecular defects, the LDL-C continuum, and gradients of phenotypic severity. J Clin Lipidol. 2016; 10(4): 970-986, doi: 10.1016/j.jacl.2016.04.009, indexed in Pubmed: 27578130.

3. Gallagher JJ, Myant NB. The affinity of low-density lipoproteins and of very-low-density lipoprotein remnants for the low-density lipoprotein receptor in homozygous familial defective apolipoprotein B-100. Atherosclerosis. 1995; 115(2): 263-272, doi: 10.1016/0021-9150(94)05528-q, indexed in Pubmed: 7661885.

4. Schaefer JR, Scharnagl H, Baumstark MW, et al. Homozygous familial defective apolipoprotein B-100. Enhanced removal of apolipoprotein E-containing VLDLs and decreased production of LDLs. Arterioscler Thromb Vasc Biol. 1997; 17(2): 348-353, doi: 10.1161/01.atv.17.2.348, indexed in Pubmed: 9081691.

5. Andersen LH, Miserez AR, Ahmad Z, et al. Familial defective apolipoprotein B-100: a review. J Clin Lipidol. 2016; 10(6): 1297-1302, doi: 10.1016/j. jacl.2016.09.009, indexed in Pubmed: 27919345. 